\title{
The Effect of Headgear Use on Concussion Injury Rates in High School Lacrosse
}

\author{
Daniel C. Herman, MD, PhD
}

Department of Physical Medicine and Rehabilitation, University of Florida, Gainesville, FL, USA

Shane V. Caswell, PhD, ATC, CSCS

Athletic Training Education Program, Sports Medicine Assessment, Research \& Testing (SMART) Laboratory, George Mason University, Manassas, VA, 20110, USA,

Patricia M. Kelshaw, PhD, LAT, ATC

Athletic Training Program, Department of Kinesiology, University of New Hampshire, Durham, $\mathrm{NH}$

Heather K. Vincent, PhD

Department of Physical Medicine and Rehabilitation, UF Health Sports Performance Center, University of Florida, Gainesville, FL, USA

Andrew E. Lincoln, ScD, MS

MedStar Sports Medicine Research Center, MedStar Health, Baltimore, MD, USA. Department of Rehabilitation Medicine, Georgetown University Medical Center, Washington, DC, USA.

Address correspondence to: Daniel C. Herman, MD, PhD; Department of Physical Medicine and Rehabilitation, University of Florida, PO Box 112727, Gainesville, FL, USA 
medRxiv preprint doi: https://doi.org/10.1101/2021.10.06.21264026; this version posted October 7, 2021. The copyright holder for this preprint (which was not certified by peer review) is the author/funder, who has granted medRxiv a license to display the preprint in perpetuity.

All rights reserved. No reuse allowed without permission.

Abstract

Objectives: The use of headgear is a controversial issue in girls' lacrosse. We compared concussion rates among high school lacrosse players wearing versus not wearing lacrosse

32 headgear.

Methods: Study participants included a sample of convenience of high schools with girls' lacrosse from across the United States. Certified athletic trainers reported athlete exposure and injury data via the National Athletic Treatment, Injury and Outcomes Network during the 2019 through 2021 seasons. The Headgear cohort was inclusive of high schools from the state of

37 Florida, which mandate the use of ASTM standard F3137 headgear, while the Non-Headgear cohort was inclusive of the remaining states, none of which have headgear mandates. Incidence CIs that excluded 1.00 were deemed statistically significant.

Results: 141 concussions (Headgear: 25; Non-Headgear: 116) and 357,225 Athlete Exposures (AE) were reported (Headgear: 91,074AE; Non-Headgear: 266,151AE) across all games and practices. Overall, the concussion injury rate per 1000AE was significantly higher in the Non-

44 Headgear cohort (0.44) than the Headgear Cohort (0.27) (IRR=1.59, 95\% CI:1.03 - 2.45). The IRR was significantly higher for the Non-Headgear cohort during games $(1.74,95 \%$ CI: 1.00 , 3.02) but not for practices $(1.42,95 \% \mathrm{CI}: 0.71,2.83)$.

47 Conclusions: These findings indicate that concussion rates among high school girls' lacrosse

48 players not wearing headgear were 59\% higher than those wearing headgear. These data support

49 the use of protective headgear to reduce the risk of concussion among high school female

50 lacrosse athletes. 
medRxiv preprint doi: https://doi.org/10.1101/2021.10.06.21264026; this version posted October 7, 2021. The copyright holder for this preprint

(which was not certified by peer review) is the author/funder, who has granted medRxiv a license to display the preprint in perpetuity.

All rights reserved. No reuse allowed without permission.

52

53 Summary

54 What are the new findings?

55

- The use of lacrosse headgear meeting the ASTM F3137 standard was associated with a

56 lower risk of experiencing a concussion injury among high school girls' lacrosse players.

57

58

How might these findings impact clinical practice in the future?

59

- Lacrosse headgear may be warranted for use for concussion risk mitigation among high

60 school girls' lacrosse players.

61

- Lacrosse headgear may be considered for concussion risk mitigation at other levels of play such as the youth or collegiate levels; further study is warranted.

63 
medRxiv preprint doi: https://doi.org/10.1101/2021.10.06.21264026; this version posted October 7, 2021. The copyright holder for this preprint (which was not certified by peer review) is the author/funder, who has granted medRxiv a license to display the preprint in perpetuity.

All rights reserved. No reuse allowed without permission.

\section{Introduction}

Girls' lacrosse continues to be the fastest growing high school sport in the United States (US).[1] Prior to the COVID-19 pandemic, high school girls' lacrosse participation grew by 53.63\% over the past decade in the US (2008-2009: $n=64,929 ; 2018-2019: n=99,750)$.[1] Girls' lacrosse is a noncontact sport; however incidental concussions[2-5] and head impacts[6-8] associated with lacrosse game-play are common. A recent epidemiological study, observed across five years (2008-09 through 2013-14) of competitive high school girls' lacrosse, demonstrated that head/face injuries accounted for the most common game-related injuries (0.92/1000 Athlete Exposures [AE]), the majority of which were concussion (0.83/1000AE).[5] Collectively, stick contact is the leading mechanism of both head impacts[7] and subsequent concussions[5] in high school girls' lacrosse.

Due to the non-contact rules for girls' lacrosse, mandated protective equipment is limited to mouthguards and eyewear.[9 10] However, in response to the growing concerns regarding the mechanisms of concussion in girls' lacrosse from incidental contact, rules allowing for the use of soft-shell headgear have been adopted as of January 1, 2017.[9] Specifically, girls' lacrosse headgear must meet the ASTM International F3137 performance standard.[11] As stated in the standard, the headgear was designed "...to address the forces of some incidental stick and ball to headgear impacts to non-goaltending field players. "[1] However, headgear effectiveness at mitigating concussion risk remains unclear.[6 12] Despite this lack of clarity, in 2018 the Florida High School Athletic Association mandated the use of headgear meeting the ASTM standard headgear for lacrosse participation.

Substantial debate exists among the lacrosse community regarding implementing headgear in a noncontact sport that often exhibits incidental contact-related injury.[13-16] 
medRxiv preprint doi: https://doi.org/10.1101/2021.10.06.21264026; this version posted October 7, 2021. The copyright holder for this preprint (which was not certified by peer review) is the author/funder, who has granted medRxiv a license to display the preprint in perpetuity.

All rights reserved. No reuse allowed without permission.

88 Competing arguments have pitted the potential benefits of protective headgear (i.e. decreasing

89 severity of impacts could thus decrease the risk of injury) versus the potential for increased aggression and related injury due to risk compensation (i.e. the Peltzman Effect).[17] Until now, there has been insufficient evidence regarding the effectiveness of lacrosse headgear for reducing

92 the risk of concussion among girls' lacrosse players to support either argument. Preliminary

93 evidence at the high school level of girls' lacrosse suggests that headgear may be associated with

94 reduced head impact magnitudes,[6] may not be associated with risk compensatory

95 behaviors,[18] and may be associated with lower rates of concussion injuries during game-

96 play.[19] Therefore, in an effort to better evaluate the implementation of headgear in high school

97 girls' lacrosse, we compared concussion rates among high school girls' lacrosse players in the

98 United States wearing headgear versus without headgear. We hypothesized that the rates of 99 concussion among those players wearing headgear would not be different compared to those 100 players not wearing headgear.

101

\section{Methods}

Our approach utilized a quasi-experimental comparison that leveraged the mandatory policy of headgear use in the state of Florida, and compared outcomes to non-headgear-

105 mandating states across the United States (US). This approach utilized an existing national high school injury registry: the High School National Athletic Treatment, Injury and Outcomes

107 Network (NATION). NATION is an athletic trainer-driven injury reporting registry which 108 utilizes a set of common data elements. It is administered by the Datalys Center for Sports Injury 109 Research and Prevention (Indianapolis, IN) and has numerous publications stemming from its 
medRxiv preprint doi: https://doi.org/10.1101/2021.10.06.21264026; this version posted October 7, 2021. The copyright holder for this preprint (which was not certified by peer review) is the author/funder, who has granted medRxiv a license to display the preprint in perpetuity.

All rights reserved. No reuse allowed without permission.

110

111

112

113

114

115

116

117

118

119

120

121

122

123

124

125

126

127

128

129

130

131

132

use.[20] Patients or the public were not involved in the design, or conduct, or reporting, or dissemination plans of our research

\section{Recruitment}

In order to obtain a high number of player activity exposures, high school athletic trainers were recruited to report data for high school girls' lacrosse to NATION. Athletic trainers (ATs) were incentivised with a $\$ 150$ payment for each full season of reporting to NATION. ATs were recruited using publicly available contact information, outreach in collaboration with the National Athletic Trainers Association and the Athletic Training Locations and Services Project, and word-of-mouth. ATs were eligible to report data for the study if: (i) their high school offered a school sponsored girls' lacrosse team, (ii) the AT provided regular onsite care and athletic training services to the athletes, and (iii) the status of a headgear mandate at the local level (i.e., Florida teams must implement headgear, versus teams from non-Florida states could not mandate headgear).

\section{Data Reporting}

ATs who agreed to participate were referred to Datalys Center, Inc, which provided training on account management and use of the system to report athlete exposure and injury data. A detailed description of the NATION injury-surveillance methods has been published.[21] In brief, ATs who participate in NATION injury-surveillance efforts collected and entered injury and exposure data into a certified electronic medical record that enabled the exporting of data to NATION.[21] Deidentified exposure and injury data were then extracted from these records and checked for errors by trained, experienced NATION data quality-control staff.[21] The NATION 
medRxiv preprint doi: https://doi.org/10.1101/2021.10.06.21264026; this version posted October 7, 2021. The copyright holder for this preprint (which was not certified by peer review) is the author/funder, who has granted medRxiv a license to display the preprint in perpetuity.

All rights reserved. No reuse allowed without permission.

133 injury-surveillance registry has been approved by the Western Institutional Review Board

134 (Puyallup, WA), and the current investigation was approved by the Institutional Review Board

135 (IRB \#201802880) at the University of Florida.

Reported concussions were operationally defined as injuries that occurred as a result of

137 participation in a girls' high school lacrosse game or practice and were diagnosed by an AT,

138 physician, or other health care professional.[21] Mechanisms of concussion were categorized as

139 player contact, surface contact, contact with equipment, or other/unknown. Time loss for the

140 concussion injuries was defined as the number of days from the injury to return to play. An

141 athlete-exposure (AE) was defined as a single athlete participating in one high school-sanctioned

142 practice or game, regardless of duration, in which the athlete was exposed to the risk of

143 injury.[21] A game exposure required that the athlete participate in the game event to be

144 considered exposed (i.e., athletes on the sideline were not included).[21] Per USA Lacrosse

145 guidelines, individual players from the No Headgear cohort (i.e., non-Florida states) were not

146 restricted from the using headgear during lacrosse participation, and the de-identification process

147 used by High School NATION precluded segregation of injuries and AEs from players using

148 headgear in the No Headgear cohort.

Power Analysis

A power analysis was performed using publicly available data from the High School

152 Reporting Information Online data registry.[22] Using data from high school girls' lacrosse from 1532014 through 2017, an estimate of 1.4 total concussions (from games and practices) per 1000

154 game exposures was used to approximate a baseline non-helmeted player concussion injury rate.

155 A Poisson-distributed model with $80 \%$ power and 5\% type 1 error rate and a 1:2 cohort ratio was 
medRxiv preprint doi: https://doi.org/10.1101/2021.10.06.21264026; this version posted October 7, 2021. The copyright holder for this preprint (which was not certified by peer review) is the author/funder, who has granted medRxiv a license to display the preprint in perpetuity.

All rights reserved. No reuse allowed without permission.

then used to obtain an estimate of 24,509 game exposures in Florida and 49,018 exposures outside of Florida in order to resolve a difference of one concussion per 1000 game exposures. Using an estimate of approximately 375 game exposures per high school (i.e., 25 players over 15 games), approximately 65 school-seasons in Florida and 130 school-seasons outside of Florida would be need to provide appropriate power for the study.

\section{Data Analysis}

Concussion incidence rates (IRs) were calculated as the number (i.e., frequency) of documented concussions divided by the athletic-exposures for games or practices where players had an opportunity to experience a concussion multiplied by 1000 . Concussions experienced by goalkeepers were excluded from the analyses. Incident rate ratios (IRRs) were calculated as the ratio of the incident rate for the No Headgear cohort divided by that for the Headgear cohort. 95\% confidence intervals $(95 \% \mathrm{CI})$ were calculated for both rates and rate ratios using standard techniques. Exploratory analyses were conducted of incidence rates based on mechanism of injury. IRRs with corresponding CIs that excluded 1.00 were deemed statistically significant.

\section{Results}

A combined 76 school-seasons of data from high schools in the state of Florida and 166 school-seasons of data from high schools outside of the state of Florida were reported during the 2019 and 2021 seasons (See Table 1). Twenty partial school-seasons of data from high schools in the state of Florida and 27 partial school-seasons of data from high schools outside of the state of Florida were reported during the 2020 season prior to cancellation due to the coronavirus pandemic. Table 1 includes the AEs reported during each of these seasons. 
medRxiv preprint doi: https://doi.org/10.1101/2021.10.06.21264026; this version posted October 7, 2021. The copyright holder for this preprint (which was not certified by peer review) is the author/funder, who has granted medRxiv a license to display the preprint in perpetuity.

All rights reserved. No reuse allowed without permission.

Over the three seasons there were a total of 141 documented concussions that occurred over 357,225 AEs, resulting in an overall rate of 0.39 concussions per $1000 \mathrm{AE}$ (95\% CI: 0.33 , 0.46) (See Table 2). The Headgear cohort experienced 25 concussions $(17.7 \%, I R=0.27$ per 1000 AE, 95\% CI: $0.17,0.38)$ while the No Headgear cohort had 116 concussions $(82.3 \%, \mathrm{IR}=0.27$ per $1000 \mathrm{AE}, 95 \% \mathrm{CI}: 0.36,0.52)$. The IRs during games were dramatically higher for both the Headgear $(0.58,95 \%$ CI: $0.29,0.88)$ and No Headgear $(1.01,95 \%$ CI: $0.78,1.24)$ cohorts than during practices. The IRRs were significantly higher for the No Headgear cohort during games $(1.74,95 \%$ CI: $1.00,3.02)$ and overall $(1.59,95 \%$ CI: $1.03,2.45)$, but not for practices $(1.42$, 95\% CI: 0.71, 2.83).

In terms of mechanism of injury, contact with stick/ball resulted in the majority of concussions $(n=74,52.5 \%)$, followed by contact with player $(n=38,27.0 \%)$ and contact with ground $(\mathrm{n}=26,18.4 \%)$ (See Table 3 ). The IRRs were not significantly higher among the No Headgear cohort for player contact with equipment $(1.77,95 \%$ CI: $0.95,3.28)$, player $(2.26,95 \%$ CI: $0.88,5.79)$, or ground $(0.93,95 \%$ CI: $0.39,2.21)$.

\section{Discussion}

Our findings provide much needed information about concussion rates among high school girls' lacrosse players in Florida, which mandates lacrosse headgear, compared to those states having no headgear mandate. We observed that girls' participating in states not mandating lacrosse headgear had a 59\% greater overall incidence of concussion than those required to wear headgear. Moreover, a 74\% greater incidence of concussion was observed during game play in states not mandating headgear. However, headgear use was not associated with any significant differences in concussion incidence during practice. Collectively, these findings suggest that use 
medRxiv preprint doi: https://doi.org/10.1101/2021.10.06.21264026; this version posted October 7, 2021. The copyright holder for this preprint (which was not certified by peer review) is the author/funder, who has granted medRxiv a license to display the preprint in perpetuity.

All rights reserved. No reuse allowed without permission.

202 of lacrosse headgear is associated with a lower incidence of concussion incidence in girls' high

203 school lacrosse.

204

205

Comparison to Previous Investigations

206

Our findings are consistent with a previous smaller investigation that studied this issue

207 regionally.[19] Baron et. al. followed girls' high school lacrosse athletes from the Public Schools

208 Athletic League of New York City, which has a headgear mandate in place. The authors

209 compared concussion rates among their cohort from the 2017 and 2018 seasons to that of the

210 High School RIO nationwide injury registry from 2009-2016. The use of headgear was

211 associated with a lower overall concussion rates (0.089 per 1000AE) compared to the nationwide

212 cohort (0.375 per 1000AE).

213 While the concussion rates of the headgear cohort were low compared to the headgear

214 cohort in the present investigation, the study by Baron et. al. was limited by the relatively small

215 number of athlete exposures (22,397AE) among the headgear cohort. In contrast, our study

216 leveraged over four times the headgear cohort AE of this prior study. Furthermore, we used a

217 contemporaneous cohort without headgear for comparison, as opposed to Baron et. al. which

218 used historical data from a previous period with a much wider range of seasons. Additionally,

219 game exposures in our study consisted of all participants playing with headgear or all

220 participants playing without headgear; conversely, the game exposures in the headgear group for

221 Baron et. al. consisted of games with one or both teams wearing headgear. Finally, all of the data

222 recorded in this study were derived from the one data collection registry with one data collection

223 technique rather than a combination of methodologies. These advantages allow for a more robust

224 interpretation of the associations of concussion incidence with headgear use in girls' lacrosse. 
medRxiv preprint doi: https://doi.org/10.1101/2021.10.06.21264026; this version posted October 7, 2021. The copyright holder for this preprint (which was not certified by peer review) is the author/funder, who has granted medRxiv a license to display the preprint in perpetuity.

All rights reserved. No reuse allowed without permission.

Mechanisms of Injury

Although not the primary purpose of the study, the relationship between headgear use, concussion and mechanisms of injury were explored. The findings show there was a reduction in the rate of concussion by nearly half with headgear in situations where equipment (i.e. ball or stick) versus player were involved. While this was not statistically significant, this is a compelling avenue for additional research. Prior research suggests the most common mechanism

232 of concussion in girl's lacrosse is via equipment versus player contact.[5] The magnitude of impacts associated with this mechanism of injury have the potential to be particularly high, with

234 linear and rotational acceleration magnitudes from ball and stick impacts second only to

235 falls.[23] Thus, any reduction in concussion risk from this mechanism is clinically important.

236 Previous investigations support the ability of headgear meeting the ASTM F3137 standard in

237 reducing impact magnitudes. Laboratory research using lacrosse headgear meeting the ASTM 238 F3137 standard report a reduction in both linear and rotational accelerations.[24] Similarly, a 239 recent study investigated the effect of headgear versus no headgear conditions on peak linear 240 accelerations and peak rotational velocities during actual game play on high school girls lacrosse

241 players instrumented with wearable sensors.[6] The headgear condition resulted in slight

242 reductions to the mean impact magnitudes experienced by the players.[6] Our findings may lend 243 support to the notion that the headgear are effective at mitigating such impacts that may result in 244 concussion among this cohort; however, further investigation is needed using study designs that 245 are appropriately powered to assess concussion incidence based on mechanism of injury. Similarly, there was a non-significant reduction in the incidence of concussion by a player versus player mechanism of injury by over half with headgear use. We are unable to 
medRxiv preprint doi: https://doi.org/10.1101/2021.10.06.21264026; this version posted October 7, 2021. The copyright holder for this preprint (which was not certified by peer review) is the author/funder, who has granted medRxiv a license to display the preprint in perpetuity.

All rights reserved. No reuse allowed without permission.

248

249

250

251

252

253

254

255

256

257

258

259

260

261

262

263

264

265

266

267

268

269

270

discern a rationale for a potential protective effect of lacrosse headgear for concussions resulting from player contact mechanisms; however, our data may provide insight into the potential role of risk compensation, also known as the Peltzman Effect.[17] This postulates that individuals may act with less caution when they have a greater level of protection; or, when applied to gameplay scenarios such as lacrosse, players may act with greater aggression towards an opponent that they feel has a greater level of protection. If the headgear was protective but significant risk compensation also occurred, players in the headgear cohort may have experienced a reduction in equipment vs player concussions but a greater rate of player versus player or player versus ground concussions. However, this was not observed, which speaks against any effect of risk compensation on the study results. Collectively, our findings along with prior observations of perceptions of headgear use,[18] may dispel some concerns regarding compensatory aggressive behaviors subsequent to headgear use in girls' lacrosse. Again, given the fact that our study was not adequately powered to make comparisons based on mechanism of injury, this possibility should be treated with caution.

\section{Limitations}

The primary limitation of this study is the lack of randomisation regarding the use of protective headgear. The use of players at high schools in the state of Florida for the headgear cohort was necessary owing to the fact that Florida is the only state in the United States with a protective headgear mandate for girls' lacrosse. Regardless, this design may introduce potential confounding elements that would bias the results. Possible confounders may be regional differences in game play and officiating between the state of Florida and the remainder of the United State. 
medRxiv preprint doi: https://doi.org/10.1101/2021.10.06.21264026; this version posted October 7, 2021. The copyright holder for this preprint (which was not certified by peer review) is the author/funder, who has granted medRxiv a license to display the preprint in perpetuity.

All rights reserved. No reuse allowed without permission.

It was assumed that all players in the No Headgear cohort in fact did not use headgear;

272 however, as noted previously, players were not restricted from using headgear and the nature of

273 the reporting system precluded segregation of data from such players in the No Headgear cohort.

274 Anecdotally, the use of headgear among states outside of Florida and in areas without a local

275 helmet mandate is exceedingly low, and thus we feel the contribution of injury and AE data from

276 athletes using headgear in the No Headgear cohort to be trivial. Furthermore, given the

277 demonstrated association of headgear use with a reduced risk of concussion, any contributions

278 from such athletes in the No Headgear cohort would serve to strengthen the findings rather than

279 diminish the relationship.

280

However, this assumption does pose another limitation to the current study. The

281 comparison cohorts included games in which all players used headgear versus when all players

282 did not use headgear; as such we are unable to make conclusions regarding games featuring

283 players in games with mixed headgear status (e.g. one team using headgear while the other team

284 does not). It is possible that any contribution from risk compensation may be different under

285 such circumstances, although the prior biomechanical study by Caswell et. al., which was

286 conducted using such an environment, suggests otherwise.[6]

Conclusion and Future Directions

The results of this study are highly encouraging for athlete safety in high school girls'

290 lacrosse. The data indicate that the use of protective headgear is associated with significantly

291 lower risk of experiencing a concussion injury; as such, we feel that this supports the use of the

292 ASTM F3137 standard headgear for the sport in this age cohort. 
294 girls' lacrosse. These may include athletes at the collegiate level or higher, as well as athletes at

295 the developmental or youth levels. A measure of caution is necessary as significant differences in

296 game play, officiating performance, body control, skill development, and neck strength are likely

297 to be present at these difference levels, which may influence the association between headgear

298 and concussion risk. In light of the current results, additional investigation is warranted for these

299 populations.

These findings also suggest that headgear may be protective in other non-contact sports

301 with moderate-high rates of concussion that do not mandate protective equipment. Formal

302 evaluation studies in such sports would be needed to confirm any protective effects and detect

303 any potential unintended consequences.

$305 \quad$ Funding

307 Committee on Standards for Athletic Equipment.

309 Competing Interests Statement relevant to the submitted manuscript. 
medRxiv preprint doi: https://doi.org/10.1101/2021.10.06.21264026; this version posted October 7, 2021. The copyright holder for this preprint (which was not certified by peer review) is the author/funder, who has granted medRxiv a license to display the preprint in perpetuity.

All rights reserved. No reuse allowed without permission.

\section{Table 1. Athlete Exposures}

\begin{tabular}{|c|c|c|c|}
\hline & No Headgear & Headgear & Overall \\
\hline Team-Seasons & & & \\
\hline $2018-2019$ & 48 & 26 & 74 \\
\hline $2019-2020^{*}$ & 27 & 20 & 47 \\
\hline $2020-2021$ & 118 & 50 & 168 \\
\hline Total & 193 & 96 & 289 \\
\hline & & & \\
\hline Athlete Exposures & & & \\
\hline $2018-2019$ & 89,504 & 26,321 & 115,825 \\
\hline $2019-2020^{*}$ & 6,656 & 6,246 & 12,902 \\
\hline $2020-2021$ & 169,991 & 58,507 & 228,498 \\
\hline & & & \\
\hline Total Games & 73,125 & 25,733 & 98,858 \\
\hline Total Practices & 193,026 & 65,341 & 258,367 \\
\hline Total Games and Practices & 266,151 & 91,074 & 357,225 \\
\hline
\end{tabular}

$314 *$ Season shortened as a result of the COVID-19 pandemic.

315

316 
medRxiv preprint doi: https://doi.org/10.1101/2021.10.06.21264026; this version posted October 7, 2021. The copyright holder for this preprint (which was not certified by peer review) is the author/funder, who has granted medRxiv a license to display the preprint in perpetuity.

All rights reserved. No reuse allowed without permission.

317 Table 2. Concussion incidence among girls' high school lacrosse players wearing headgear vs.

318 not wearing headgear by game type

\begin{tabular}{|l|c|c|c|c|c|c|}
\hline & \multicolumn{2}{|c|}{ Overall } & \multicolumn{2}{c|}{ Games } & \multicolumn{2}{c|}{ Practices } \\
& $\begin{array}{c}\text { No } \\
\text { Headgear }\end{array}$ & Headgear & $\begin{array}{c}\text { No } \\
\text { Headgear }\end{array}$ & Headgear & $\begin{array}{c}\text { No } \\
\text { Headgear }\end{array}$ & Headgear \\
\hline Frequency & 116 & 25 & 74 & 15 & 42 & 10 \\
\hline AEs & 266,151 & 91,074 & 73,125 & 25,733 & 193,026 & 65,341 \\
\hline $\begin{array}{l}\text { Incident Rate } \\
\text { per 1000 }\end{array}$ & 0.44 & 0.27 & 1.01 & 0.58 & 0.22 & 0.15 \\
$\begin{array}{l}\text { AEs (95\% } \\
\text { CI) }\end{array}$ & $(0.36,0.52)$ & $(0.17,0.38)$ & $(0.78,1.24)$ & $(0.29,0.88)$ & $(0.15,0.28)$ & $(0.06,0.25)$ \\
\hline $\begin{array}{l}\text { Incident Rate } \\
\text { Ratio (95\% } \\
\text { CI) }\end{array}$ & \multicolumn{2}{|l|}{$1.59(1.03,2.45)$} & \multicolumn{2}{|c|}{$1.74(1.00,3.02)$} & $1.42(0.71,2.83)$ \\
\hline
\end{tabular}

AEs: Athletic-exposures

320 IRR: Incident Rate Ratio (Headgear cohort is the reference)

321

322 
medRxiv preprint doi: https://doi.org/10.1101/2021.10.06.21264026; this version posted October 7, 2021. The copyright holder for this preprint (which was not certified by peer review) is the author/funder, who has granted medRxiv a license to display the preprint in perpetuity.

All rights reserved. No reuse allowed without permission.

323 Table 3. Concussion incidence among girls' high school lacrosse players wearing headgear vs.

324 not wearing headgear by mechanism of concussion

\begin{tabular}{|c|c|c|c|c|c|c|}
\hline & \multicolumn{2}{|c|}{ Equipment } & \multicolumn{2}{|c|}{ Player } & \multicolumn{2}{|c|}{ Ground } \\
\hline & $\begin{array}{c}\text { No } \\
\text { Headgear }\end{array}$ & Headgear & $\begin{array}{c}\text { No } \\
\text { Headgear }\end{array}$ & Headgear & $\begin{array}{c}\text { No } \\
\text { Headgear }\end{array}$ & Headgear \\
\hline Frequency & 62 & 12 & 33 & 5 & 19 & 7 \\
\hline AEs & 266,151 & 91,074 & 266,151 & 91,074 & 266,151 & 91,074 \\
\hline $\begin{array}{l}\text { Incident Rate } \\
\text { per } 1000 \\
\text { AEs }(95 \% \\
\text { CI })\end{array}$ & $\begin{array}{c}0.23 \\
(0.17,0.29)\end{array}$ & $\begin{array}{c}0.13 \\
(0.06,0.21)\end{array}$ & $\begin{array}{c}0.12 \\
(0.08,0.17)\end{array}$ & $\begin{array}{c}0.05 \\
(0.01,0.10)\end{array}$ & $\begin{array}{c}0.22 \\
(0.15,0.28)\end{array}$ & $\begin{array}{c}0.08 \\
(0.02,0.13)\end{array}$ \\
\hline $\begin{array}{l}\text { Incident Rate } \\
\text { Ratio }(95 \% \\
\text { CI) }\end{array}$ & \multicolumn{2}{|c|}{$1.77(0.95,3.28)$} & \multicolumn{2}{|c|}{$2.26(0.88,5.79)$} & \multicolumn{2}{|c|}{$0.93(0.39,2.21)$} \\
\hline
\end{tabular}

AEs: Athletic-exposures

326 IRR: Incident Rate Ratio (Headgear cohort is the reference)

327 "Other" mechanism (n=3) not included 
medRxiv preprint doi: https://doi.org/10.1101/2021.10.06.21264026; this version posted October 7, 2021. The copyright holder for this preprint (which was not certified by peer review) is the author/funder, who has granted medRxiv a license to display the preprint in perpetuity.

All rights reserved. No reuse allowed without permission.

\section{References}

1. NFHS (National Federation of State High School Associations): High School Participation Survey Archive. Online, 2019.

2. Caswell SV, Lincoln AE, Almquist JL, et al. Video incident analysis of head injuries in high school girls' lacrosse. Am J Sports Med 2012;40(4):756-62.

3. Lincoln AE, Caswell SV, Almquist JL, et al. Effectiveness of the women's lacrosse protective eyewear mandate in the reduction of eye injuries. Am J Sports Med 2012;40(3):611-4.

4. Lincoln AE, Caswell SV, Almquist JL, et al. Trends in concussion incidence in high school sports: a prospective 11-year study. Am J Sports Med 2011;39(5):958-63.

5. Pierpoint LA, Caswell SV, Walker N, et al. The First Decade of Web-Based Sports Injury Surveillance: Descriptive Epidemiology of Injuries in US High School Girls' Lacrosse (2008-2009 Through 20132014) and National Collegiate Athletic Association Women's Lacrosse (2004-2005 Through 20132014). J Athl Train 2019;54(1):42-54.

6. Caswell SV, Kelshaw PM, Lincoln AE, et al. The Effects of Headgear in High School Girls' Lacrosse. Orthop J Sports Med 2020;8(12):2325967120969685.

7. Caswell SV, Lincoln AE, Stone H, et al. Characterizing Verified Head Impacts in High School Girls' Lacrosse. Am J Sports Med 2017;45(14):3374-81.

8. Cortes N, Lincoln AE, Myer GD, et al. Video Analysis Verification of Head Impact Events Measured by Wearable Sensors. Am J Sports Med 2017;45(10):2379-87.

9. Women's Rules. US Lacrosse. , 2016.

10. Carter EA, Westerman BJ, Lincoln AE, et al. Common game injury scenarios in men's and women's lacrosse. Int J Inj Contr Saf Promot 2010;17(2):111-8.

11. ASTM F3137 -15 Standard Specification for Headgear Used in Women's Lacrosse (Excluding Goalkeepers): ASTM International, 2015.

12. Kelshaw PM, Gould TE, Jesunathadas M, et al. Laboratory Performance Evaluation of Pristine and Used Headgear for Girls' Lacrosse. J Appl Biomech 2019;35(4):297-302.

13. US Lacrosse Statement on Florida Girls' Headgear Mandate.

14. Pennington B. As Concussion Worries Rise, Girls' Lacrosse Turns to Headgear. The New York Times November 23, 2017.

15. Pennington B. With Headgear Here, Girls' Lacrosse Just Got Safer. Or Did It? The New Year Times February 16, 2011.

16. Schwarz A. In Women's Lacrosse, Headgear Could Make the Game Rougher. The New York Times February 16, 2011.

17. Peltzman. The Effects of Automobile Safety Regulation. J Polit Econ. 1975;83(4):677-725.

18. Kelshaw P, Hepbrun L, Lindsey B, et al. Girls' Lacrosse Players Attitudes Towards Protective Headgear. J Athl Train. 2018;53(6):S-310.

19. Baron SL, Veasley SJ, Kingery MT, et al. Decreased Injury Rate Following Mandated Headgear Use in Women's Lacrosse. Bull Hosp Jt Dis (2013) 2020;78(4):260-65.

20. NATION Publications.

21. Dompier TP, Marshall SW, Kerr ZY, et al. The National Athletic Treatment, Injury and Outcomes Network (NATION): Methods of the Surveillance Program, 2011-2012 Through 2013-2014. J Athl Train 2015;50(8):862-9.

22. High School RIO Study Reports.

23. Clark JM, Hoshizaki TB, Gilchrist MD. Assessing women's lacrosse head impacts using finite element modelling. J Mech Behav Biomed Mater 2018;80:20-26. 
medRxiv preprint doi: https://doi.org/10.1101/2021.10.06.21264026; this version posted October 7, 2021. The copyright holder for this preprint (which was not certified by peer review) is the author/funder, who has granted medRxiv a license to display the preprint in perpetuity.

All rights reserved. No reuse allowed without permission.

377 24. Mclver KG, Sankaran GN, Lee $P$, et al. Impact attenuation of male and female lacrosse helmets using 378 a modal impulse hammer. J Biomech 2019;95:109313.

379 